\title{
THE OXFORD HANDBOOK OF KARL MARX
}

\author{
Edited by \\ Matt Vidal (Loughborough University London) \\ Tony Smith (Iowa State University) \\ Tomás Rotta (University of Greenwich) \\ Paul Prew (Minnesota State University, Mankato) \\ Oxford University Press \\ http://www.oxfordhandbooks.com/view/10.1093/oxfordhb/9780190695545.001.0001/ \\ oxfordhb-9780190695545
}

Introduction

1. The enduring relevance of Karl Marx

Paul Prew, Tomas Rotta, Tony Smith, Matt Vidal

Part I. Foundations

2. Historical materialism

Paul Blackledge (London South Bank University)

3. Class and class struggle

Henry Heller (University of Manitoba)

4. Forces of production and relations of production

David Laibman (Brooklyn College)

5. The eight steps in Marx's dialectical method

Bertell Ollman (NYU)

6. Ideology as alienated socialization

Jan Rehmann (Union Theological Seminary)

7. Marx's conceptualisation of value in Capital

Geert Reuten (Amsterdam)

8. Value and class

Alan Freeman (Geopolitical Economy Research Group)

9. Money

Leda Paulani (University of São Paulo) 
10. Capital

Andrew Kliman (Pace)

11. Marx's critical concept of capital

Patrick Murray (Creighton)

12. The Grammar of Capital: Wealth in-against-and-beyond Value

John Holloway (Autonomous University of Puebla)

13. Work and exploitation in capitalism: The labor process and the valorization process Matt Vidal (Loughborough University London)

14. Capital in general and competition: the production and distribution of surplus-value Fred Moseley (Mount Holyoke)

15. Reproduction and crisis in capitalist economies

Deepankar Basu (University of Massachusetts)

16. The Capitalist State and State Power

Bob Jessop (University of Lancaster)

17. Capitalist social reproduction: the contradiction between production and social reproduction under capitalism Martha E. Gimenez (UC Boulder)

18. Marx, Technology, and the Pathological Future of Capitalism Tony Smith (Iowa State University)

19. Alienation, or why capitalism is bad for us Dan Swain (Czech University of Life Sciences)

20. The commodification of knowledge and information Tomás Rotta (University of Greenwich) and Rodrigo Teixeira (Pontifícia Universidade Católica (PUC-SP), Brazil)

Part II. Labor, class \& social divisions

21. Labor unions and movements Barry Eidlin (McGill)

22. Migration and the mobility of labor Nicholas De Genova (King's College London) 
23. Race, class, and revolution in the in the twenty-first century: lessons from the League of Revolutionary Black Workers

Walda Katz-Fishman (Howard) and Jerome Scott (Project South: Institute for the Elimination of Poverty \& Genocide)

24. Nationalism, class and revolution

Kevin Anderson (UC Santa Barbara)

25. Hegemony: A Theory of National-Popular Class Politics

Mark McNally (University of the West of Scotland)

Part III. Capitalist states \& spaces

26. Capitalist crises and the state Leo Panitch (York) and Sam Gindin (York)

27. European "integration" Magnus Ryner (King's)

28. The urbanization of capital and the production of capitalist natures Erik Swyngedouw (Manchester)

Part IV. Accumulation, crisis \& class struggle in the core countries

29. Stages of Capitalism and Social Structures of Accumulation: A long view Terrence McDonough (National University of Ireland, Galway)

30. Geriatric capitalism: Stagnation and crisis in the Atlantic postfordist accumulation regime Matt Vidal (King's)

31. Sociopoiesis: Understanding Crisis in the Capitalist World-System through Complexity Sciences Paul Prew (Minnesota State University, Mankato)

32. Towards a Marxist theory of financialized capitalism Jeff Powell (University of Greenwich)

33. Metabolic Rifts and the Ecological Crisis Brett Clark (University of Utah), John Bellamy Foster (University of Oregon) and Stefano B. Longo (North Carolina State University) 
Part V. Accumulation, crisis \& class struggle in the peripheral and semi-peripheral countries

34. Global capital accumulation and the specificity of Latin America Guido Starosta (Universidad Nacional de Quilmes)

35. The Unresolved Agrarian Question in South Asia Debarshi Das (Indian Institute of Technology, Guwahati)

36. Asia and the shift in Marx's conception of revolution and history Chun Lin (LSE)

37. Analyzing the Middle East Gilbert Achcar (SOAS)

38. Primitive accumulation in post-Soviet Russia David Mandel (Universite du Quebec a Montreal)

Part VI. Alternatives to capitalism

39. Marx's concept of socialism

Peter Hudis (Oakton Community College)

40. Democratic socialist planning Pat Devine (University of Manchester)

41. The Continuing Relevance of the Marxist Tradition for Transcending Capitalism Erik Olin Wright (University of Wisconsin-Madison) 